\title{
EPIDEMIOLOGY OF TICK-BORNE ENCEPHALITIS IN POLAND (2010-2019) AND THE IMPACT OF THE COVID-19 PANDEMIC ON THE NOTIFIED INCIDENCE OF THE DISEASE
}

\section{EPIDEMIOLOGIA KLESZCZOWEGO ZAPALENIA MÓZGU W POLSCE W LATACH 2010-2019 I WPŁYW PANDEMII COVID-19 NA RAPORTOWANĄ ZAPADALNOŚĆ NA TE CHOROBE}

\author{
${ }^{1}$ Medical University of Bialystok, Department of Infectious Diseases and Neuroinfections, \\ Uniwersytet Medyczny w Białymstoku, Klinika Chorób Zakaźnych i Neuroinfekcji \\ ${ }^{2}$ Medical University of Bialystok, Department of Pediatric Infectious Diseases, \\ Uniwersytet Medyczny w Białymstoku, Klinika Obserwacyjno-Zakaźna Dzieci
}

\section{ABSTRACT}

INTRODUCTION. Tick-borne encephalitis (TBE) is endemic in many parts of Eurasia including countries previously considered to be free from the disease. The incidence of TBE is changing owing to various ecological and climatic factors. The factors influencing the variability of the number of TBE cases are still under investigation. In 2020 the new coronavirus SARS-CoV-2 emerged causing COVID-19 pandemic. Governments have reorganized health care systems to contain a surge of COVID-19 cases and avoid hospital overload. Moreover, new measures have modified several aspects of social habits leading to a change in the incidence of numerous diseases. We aimed to evaluate the epidemiology of TBE in the last decade (2010-2019) and to demonstrate the impact of the surge of SARS-CoV-2 infections on the TBE incidence as reported to a national surveillance database.

MATERIAL AND METHODS. We performed the analysis of the TBE notification from the epidemiologic reports in the years 2010-2019 and in the pandemic year 2020 at a national and regional level in Poland. We included data from two infectious disease departments located in the most TBE-prevalent province of Poland.

RESULTS. Most cases of TBE occur in two provinces of Northeastern Poland from May to December. The increasing temporal trend occurred in Poland in 2016-2017. The increased number of cases of COVID-19 coincided with a reduction of the number of the reported TBE cases in 2020.

CONCLUSIONS. Tick-borne encephalitis virus activity in Poland is invariably concentrated in endemic regions of Northeastern Poland fluctuating considerably from year to year. The decrease of TBE incidence with surge of COVID-19 patients conceivably resulted from underreporting due to limited access to specialized diagnostics. In endemic areas, TBE should be included in the differential diagnostics in all the cases when the central nervous system infection in suspected.

Key words: tick-borne encephalitis, incidence, COVID-19

\section{STRESZCZENIE}

WSTĘP. Kleszczowe zapalenie mózgu (kzm) występuje endemicznie na terenach Eurazji i w ostatnich latach coraz częściej pojawia się w krajach dotychczas wolnych od tej choroby. Zapadalność na kzm zależy od wielu czynników klimatycznych i środowiskowych. Czynniki wpływające na liczbę przypadków kzm u ludzi wciąż są badane. W 2020 roku pojawił się na świecie nowy koronawirus SARS-CoV-2 powodując pandemię choroby COVID-19. W odpowiedzi dokonano reorganizacji ochrony zdrowia, by powstrzymać wzrost liczby przypadków COVID-19 i uniknąć przeciążenia szpitali. Ponadto wprowadzone obostrzenia spowodowały zmianę zachowań ludzi, co przełożyło się na zapadalność na wiele chorób. Celem pracy była ocena epidemiologii kzm w ostatniej

(C) National Institute of Public Health - National Institute of Hygiene / Narodowy Instytut Zdrowia Publicznego - Państwowy Zakład Higieny 
dekadzie (2010-2019) i analiza wpływu wzrastającej liczby przypadków zakażeń SARS-CoV-2 na raportowaną do służb sanitarnych zapadalność na kzm.

MATERIAŁ I METODY. Przeprowadzono analizę raportów epidemiologicznych zachorowań na kzm w latach 2010-2019 oraz w roku pandemicznym 2020 w całej Polsce oraz w poszczególnych województwach. Ponadto analizowano dane $\mathrm{z}$ dwóch oddziałów chorób zakaźnych zlokalizowanych $\mathrm{w}$ regionie o największej w Polsce zapadalności na kzm.

WYNIKI. Większość przypadków kzm zanotowano w dwóch województwach północno-wschodniej Polski w okresie od maja do grudnia. Wzrastający trend zachorowań w badanej dekadzie przypadał na lata 2016-17. Wraz ze wzrastającą liczbą zachorowań na COVID-19 w 2020 roku notowano spadek liczby raportowanych przypadków kzm.

WNIOSKI. Aktywność wirusa kleszczowego zapalenia mózgu w Polsce niezmiennie koncentruje się w endemicznych rejonach Polski północno-wschodniej ze znaczną zmiennością w poszczególnych latach. Spadek zapadalności na kzm w Polsce notowany wraz ze wzrostem zachorowań na COVID-19 może być spowodowany zmniejszeniem liczby zgłaszanych przypadków wynikającym z ograniczonego dostępu do specjalistycznej diagnostyki. Zachorowanie na kzm powinno być brane pod uwagę na terenach endemicznych w każdym przypadku podejrzenia infekcji ośrodkowego układu nerwowego.

Slowa kluczowe: kleszczowe zapalenie mózgu, zapadalność, COVID-19

\section{INTRODUCTION}

Tick-borne encephalitis (TBE) is a common disease in Eurasia from Central Europe to the Far East. In recent years, there have been cases of TBM in European countries previously considered free from the disease $(1,2)$. Also, a significant increase in the incidence in countries where the disease is endemic (3) has been observed. The tick-borne encephalitis virus (TBEV) belongs to the genus Flavivirus, which also includes the world's widespread dengue, Zika, West Nile virus and yellow fever virus from which the genus is named (flavus - lat. yellow). TBEV circulates freely in an ecosystem of vertebrates and ticks which constitute the vector of the disease. The disease is transmitted to humans by tick bite, although the possibility of infection by eating unpasteurized animal milk has also been described $(4,5)$. The alimentary route of TBEV transmission is of less importance as the vast majority of consumed milk is pasteurized. The incidence of TBE in humans shows high annual variability depending on a number of factors. The number of new cases of the disease in humans depends on weather factors $(6,7)$, the presence of ticks in the environment, and the periodic fluctuations in the number of small mammal species constituting a reservoir of ticks (8-9).

Moreover, it has been shown that the incidence of TBE reported to the sanitary authorities may be underestimated (10-11). Cases of hospitalization are largely reported; however, mild cases are not. Factors such as the availability of health care facilities specializing in the diagnosis and treatment of infectious inflammatory diseases of the nervous system also affect the reported incidence of TBE.

\section{WSTĘP}

Kleszczowe zapalenie mózgu (kzm) jest chorobą powszechnie występującą w Eurazji na terenach od Europy Centralnej po Daleki Wschód Azji. W ostatnich latach obserwuje się przypadki zachorowań na kzm w krajach europejskich wolnych uprzednio od choroby $(1,2)$ oraz istotny wzrost zachorowań w krajach, gdzie choroba występuje endemicznie (3). Wirus kzm (Tick-borne encephalitis virus - TBEV) należy do rodzaju Flavivirus, który obejmuje także szeroko rozpowszechnione na świecie wirusy dengi, Zika, wirus Zachodniego Nilu i wirus żółtej gorączki, od której to choroby pochodzi nazwa rodzaju (flavus - łac. żółty). TBEV swobodnie krąży w ekosystemie złożonym z kręgowców oraz stanowiących wektor choroby kleszczy. Choroba może być przeniesiona na człowieka przez ukłucie kleszcza, choć opisano również możliwość zakażenia przez spożywanie niepasteryzowanego mleka zwierząt $(4,5)$. Droga pokarmowa przenoszenia kzm ma mniejsze znaczenie, gdyż zdecydowana większość spożywanego mleka jest poddawana uprzedniej pasteryzacji. Zapadalność na kzm u ludzi wykazuje dużą coroczną zmienność zależną od szeregu czynników. . Liczba nowych przypadków choroby u ludzi zależy od czynników pogodowych (6, 7), obecności kleszczy w środowisku, a także podlegającej okresowym wahaniom liczebności gatunków małych ssaków stanowiących rezerwuar kleszczy $(8,9)$.

Ponadto wykazano, iż raportowana do władz sanitarnych zapadalność na kzm jest faktycznie niedoszacowana $(10,11)$. Zgłaszane są w dużej mierze przypadki hospitalizowane $\mathrm{z}$ pominięciem przypadków o łagodnym przebiegu. Na raportowaną zapadalność na kzm wpływają również czynniki, takie jak dostępność placówek służby zdrowia, specjalizujących się w dia- 
The available literature lacks comprehensive analysis of the incidence of TBE in Poland in the last decade. In addition, in the first months of 2020, the first cases of SARS-CoV-2 coronavirus infection which subsequently caused the global COVID-19 pandemic were reported in Europe. The restrictions introduced due to the pandemic, including social distancing and covering of the mouth and nose, significantly limited the transmission of pathogens by droplets and partly by air. In addition, changes in the incidence of a number of other diseases have also been observed as the pandemic developed. The COVID-19 pandemic has changed people's behavior, influencing the spread of diseases. It also led to reorganizing healthcare. In the following months, hospitals were being converted into COVID-19 treatment centers. Infectious disease wards were the primary choice for such changes. This significantly limited the possibilities of diagnosing infectious diseases other than COVID-19, including TBE.

\section{THE AIM OF THE STUDY}

The aim of the study was to analyze TBE cases over a ten-year period (2010-2019) and to assess the geographical distribution of the disease in Poland. Moreover, the data on the incidence of TBE in the studied period were compared to the data obtained in 2020, when the COVID-19 pandemic occurred, to assess its impact on the reported number of TBE cases.

\section{MATERIALS AND METHODS}

We conducted a retrospective analysis of TBE incidence in the ten years 2010-2019 and in 2020. The source of information on the incidence of TBE were reports on infectious diseases published by the National Institute of Public Health - National Institute of Hygiene in Warsaw. Information on the number of diagnosed SARS-CoV-2 coronavirus infections was obtained from reports published by the Ministry of Health. The analysis also included the number of hospitalizations due to TBE in 2015-2020 of adult and pediatric patients at the Department of Infectious Diseases and Neuroinfections and the Department of Pediatric Infectious Diseases at the Medical University of Bialystok.

Statistical methods. The consistency of the distributions of the analyzed variables of the continuous type with the normal distribution was verified. Summary statistics for continuous variables are presented as a median and interquartile range. Nominal and categorical variables are presented as frequencies. The comparison of the distributions of gnozowaniu i leczeniu infekcyjnych chorób zapalnych układu nerwowego.

W dostępnej literaturze brakuje kompleksowej analizy zapadalności na kzm w Polsce w ostatnim dziesięcioleciu. W pierwszych miesiącach 2020 roku na terenie Europy pojawiły się pierwsze przypadki zakażenia koronawirusem SARS-CoV-2, powodującym następnie światową pandemię choroby COVID-19. Wprowadzone z związku z pandemią obostrzenia, w tym nakaz dystansu społecznego oraz nakaz zasłaniania ust i nosa, w istotny sposób ograniczyły transmisję patogenów drogą kropelkową i po części powietrzną. Ponadto wraz $z$ rozwojem pandemii zaobserwowano również zmiany zapadalności dotyczące szeregu innych chorób. Pandemia COVID-19 zmieniła zachowania ludzi, co wpłynęło na rozprzestrzenianie chorób, a także doprowadziła do przeorganizowania opieki zdrowotnej. W kolejnych miesiącach szpitale były przekształcane $\mathrm{w}$ ośrodki leczenia choroby COVID-19. W pierwszej kolejności przekształcenia dotyczyły oddziałów zakaźnych. W znaczący sposób ograniczyło to możliwości diagnostyki innych niż COVID-19 chorób zakaźnych, w tym kleszczowego zapalenia mózgu.

\section{CEL PRACY}

Celem pracy była analiza zachorowań na kleszczowe zapalenie mózgu na przestrzeni kolejnych dziesięciu lat (2010-2019) wraz z oceną dystrybucji geograficznej choroby w Polsce.

Ponadto dane o zapadalności na kzm w badanym okresie odniesiono do danych uzyskanych w roku 2020, w którym wystąpiła pandemia choroby COVID-19, celem oceny jej wpływu na notowaną liczbę przypadków kleszczowego zapalenia mózgu.

\section{MATERIAŁ I METODY}

Przeprowadzono retrospektywną analizę zapadalności na kleszczowe zapalenie mózgu w okresie dziesięciu lat 2010-2019 oraz w roku 2020. Źródłem informacji o zapadalności na kzm były meldunki o zachorowaniach na choroby zakaźne publikowane przez Narodowy Instytut Zdrowia Publicznego - Państwowy Zakład Higieny w Warszawie. Informacje o liczbie zdiagnozowanych zakażeń koronawirusem SARS-CoV-2 czerpano z raportów ogłaszanych przez Ministerstwo Zdrowia. Analiza objęła również liczbę hospitalizacji z rozpoznaniem kzm w latach 2015-2020 pacjentów dorosłych i dzieci odpowiednio w Klinice Chorób Zakaźnych i Neuroinfekcji oraz Klinice Obserwacyjno-Zakaźnej Dzieci Uniwersytetu Medycznego w Białymstoku.

Metody statystyczne. Przeprowadzono weryfikację zgodności rozkładów analizowanych zmiennych typu ciągłego z rozkładem normalnym. Statystyki podsumo- 
continuous type variables was carried out using the Mann-Whitney U test. Differences were considered statistically significant when $p$-value $<0.05$.

\section{RESULTS}

The incidence of TBE in Poland, expressed as the number of cases per 100,000 inhabitants in the period 2010-2019 in individual provinces, is presented in Figure 1 (Fig.1). The incidence of TBE in Poland in particular months of the year in the ten-year period (2010-2019) is shown in Figure 2 (Fig.2). In Poland, a systematic increase in the incidence of the wujące dla zmiennych ciągłych zostały przedstawione jako mediana i rozstęp międzykwartylowy. Zmienne nominalne i skategoryzowane zaprezentowano jako częstości. Porównanie rozkładów zmiennych typu ciągłego przeprowadzono za pomocą testu Manna-Whitneya. Różnice uznawano za statystycznie istotne, gdy wartość $p<0,05$.

\section{WYNIKI}

Zapadalność na kzm w Polsce wyrażoną jako liczbę przypadków na 100 tysięcy mieszkańców w okresie 2010-2019 w poszczególnych województwach przedsta-

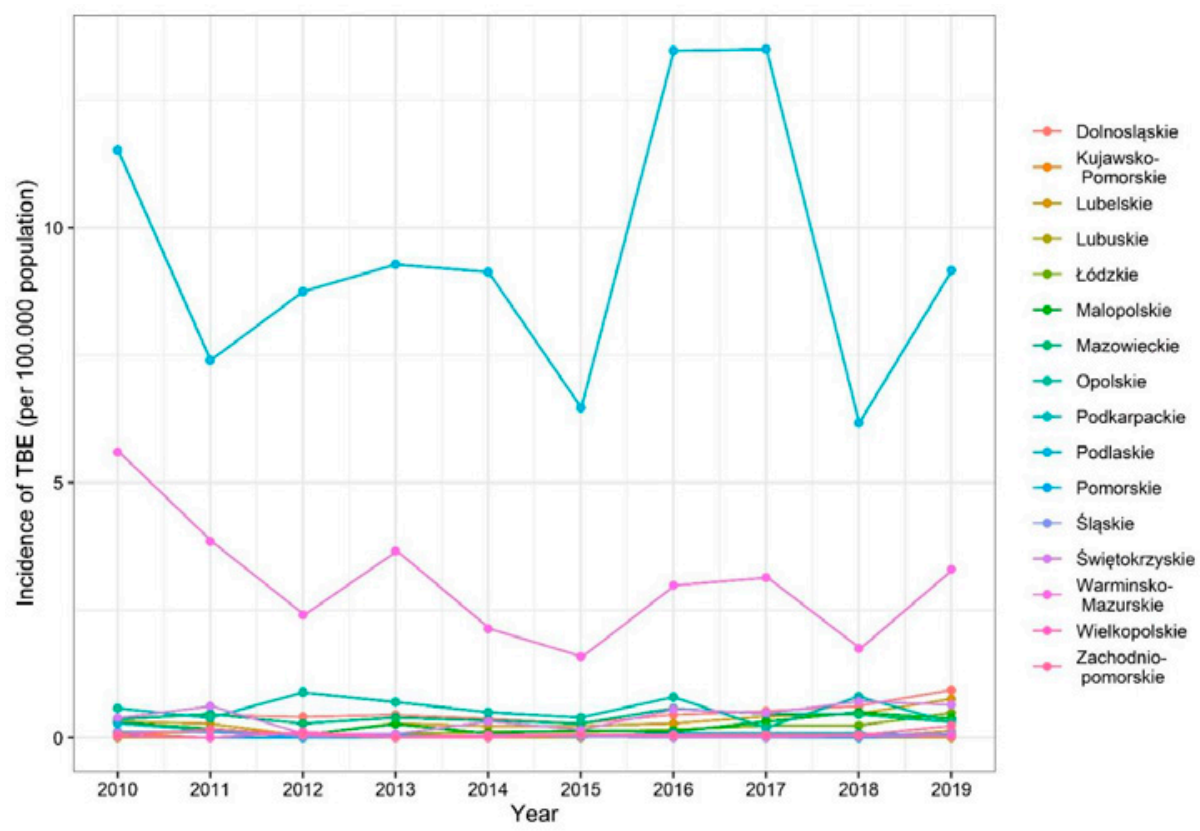

Fig. 1. Regional distribution of incidence of TBE in the provinces of Poland 2010-2019 Ryc. 1. Zapadalność na kleszczowe zapalenie mózgu (kzm) w poszczególnych województwach w okresie 2010-2019

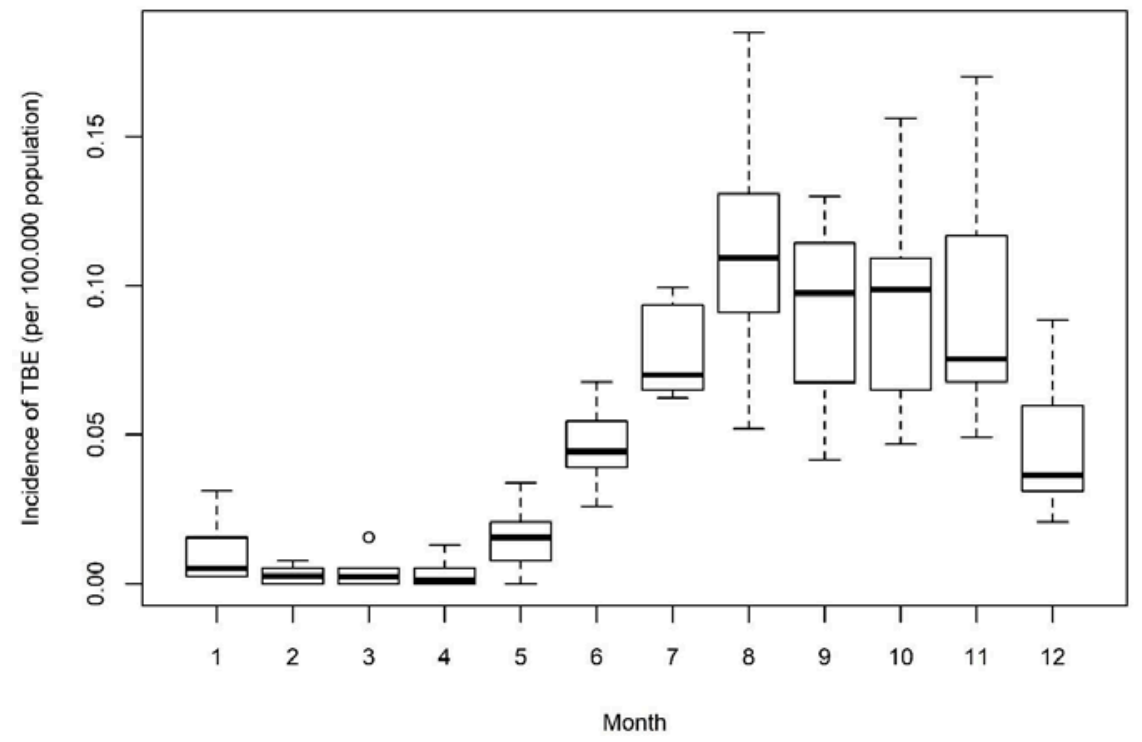

Fig. 2. Incidence of TBE in consecutive months between 2010 and 2019

Ryc. 2. Zapadalność na kzm w kolejnych miesiącach okresu 2010-2019 
COVID-19 disease has been observed since August 2020. The relationship between the observed increase in the number of people infected with SARS-CoV-2 virus and the number of reported cases of TBE was assessed. The conducted analysis showed that the average incidence of TBE in August-December in 2020 was significantly lower than the average incidence in August-December in 2010-2019; values presented as median (Q1; Q3) were 0.0469 (0.0156; $0.0625)$ and $0.0885(0.0606 ; 0.1118)$, respectively, $\mathrm{p}=$ 0.016 . The average incidence of TBE in January-July in 2020 compared to the incidence in January-July in 2010-2019 did not differ significantly; the median (Q1; Q3) was 0.0234 (0.0182; 0.0261) and 0.0078 (0.0026; 0.0377 ), respectively, $\mathrm{p}=0.0932(\mathrm{NS})$. The above relationships are presented graphically in Figure 3 (Fig.3). In addition, Figure 4 shows the average incidence of TBE in subsequent months (2010-2019) and the incidence value from 2020 in relation to the number of confirmed cases of SARS-CoV-2 (A) infection and the number of deaths of people infected with this coronavirus (B) (Fig.4). Figure 5 shows the number of adult and pediatric patients hospitalized at the clinics of the Medical University of Bialystok in 2015-2020 (Fig.5). wiono na rycinie 1 (Ryc.1). Zapadalność na kzm w Polsce w poszczególnych miesiącach roku w dziesięcioletnim okresie (2010-2019) przedstawia rycina 2 (Ryc.2). W 2020 roku w Polsce od miesiąca sierpnia obserwowano systematyczny wzrost zachorowań na chorobę COVID-19. Dokonano oceny związku obserwowanego wzrostu liczby zakażonych wirusem SARS-CoV-2 z liczbą raportowanych przypadków kzm. Przeprowadzona analiza wykazała, że przeciętna zapadalność na kzm w miesiącach sierpień-grudzień w roku 2020 była istotnie niższa niż przeciętna zapadalność notowana w miesiącach sierpień-grudzień z lat 2010-2019; wartości przedstawione jako mediana (Q1; Q3) wyniosły odpowiednio $0,0469(0,0156 ; 0,0625)$ oraz $0,0885(0,0606$; $0,1118), p=0,016$. Natomiast przeciętna zapadalność na kzm z miesięcy styczeń-lipiec w roku $2020 \mathrm{w}$ porównaniu do zapadalności z miesięcy styczeń-lipiec z lat 20102019 nie różniła się istotnie; mediana(Q1; Q3) wyniosła odpowiednio oraz $0,0234(0,0182 ; 0,0261)$ oraz 0,0078 $(0,0026 ; 0,0377), \mathrm{p}=0,0932$ (NS). Powyższe zależności przedstawiono graficznie na rycinie 3 (Ryc. 3). Ponadto na rycinie 4 zilustrowano średnią zapadalność na kzm w kolejnych miesiącach (lata 2010-2019) oraz wartość zapadalności z roku $2020 \mathrm{w}$ odniesieniu do liczby potwierdzonych przypadków zakażenia SARS-CoV-2 (A) oraz liczby zgonów osób zakażonych tym koronawirusem (B) (Ryc. 4). Na rycinie 5 przedstawiono liczbę pacjentów dorosłych i dzieci hospitalizowanych w Klinikach Uniwersytetu Medycznego w Białymstoku w latach 2015-2020 (Ryc.5).

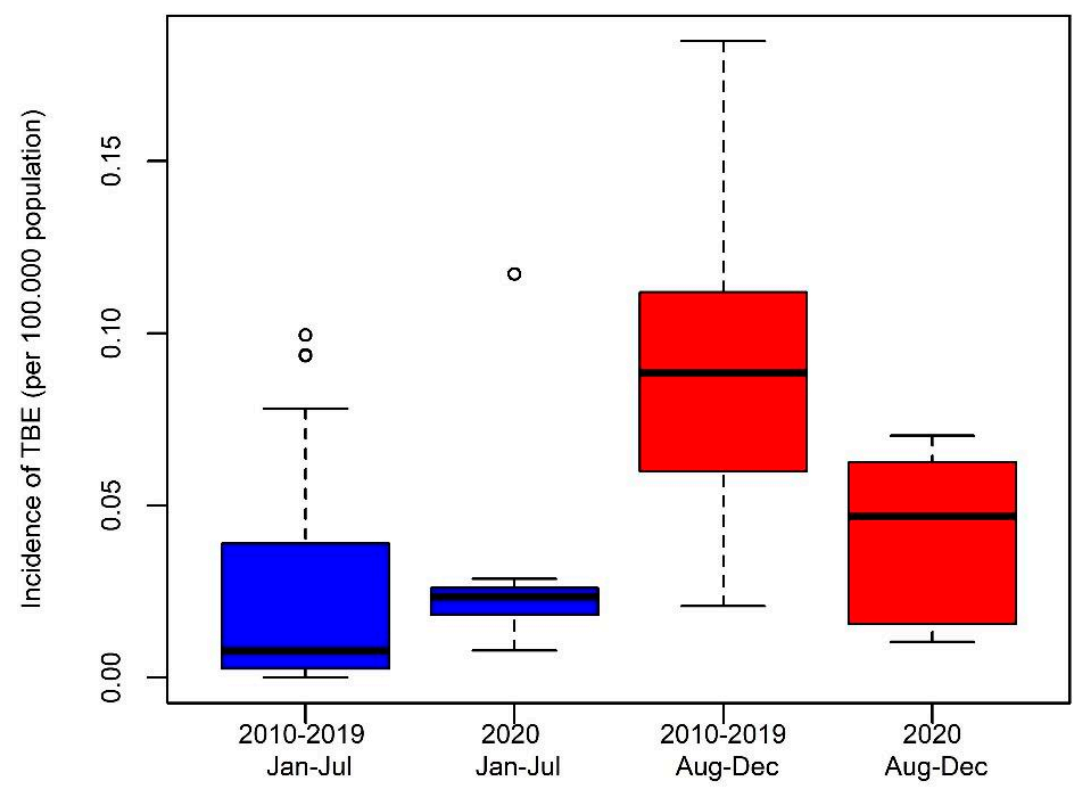

Fig. 3. Comparison of incidence of TBE in the years 2010-2019 vs 2020 from January to July (Jan-Jul) and from August to December (Aug-Dec)

Ryc. 3. Porównanie zapadalności na kzm w latach 2010-2019 oraz w roku 2020 w miesiącach styczeń - lipiec (Jan-Jul) oraz sierpień - grudzień (Aug-Dec). 
A)

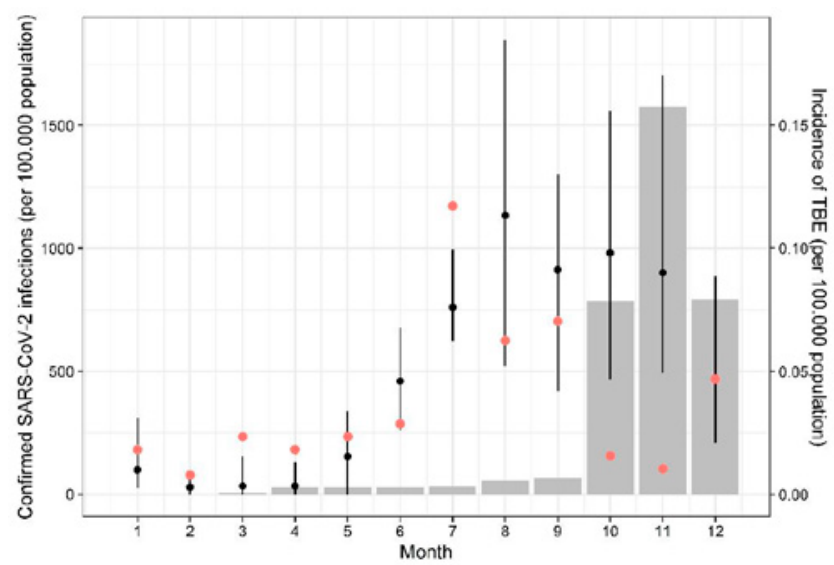

B)

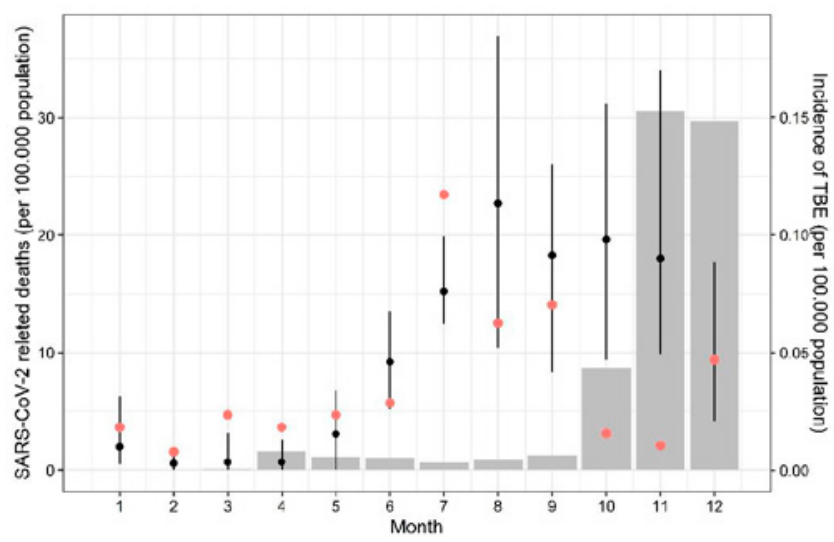

Fig. 4. TBE incidence in consecutive months of 20102019 (black) and 2020 (red). Dots represent mean value. Whiskers represent min and max value. Bars represent number of confirmed cases of SARS-CoV-2 infections (A) and number of deaths related to SARS-CoV-2 infections (B) per 100,000 population.

Ryc. 4. Miesięczna zapadalność na kzm w latach 2010-2019 (kolor czarny) i w roku 2020 (kolor czerwony). Punkty reprezentują wartości średnie. Wąsy reprezentują wartości minimalne i maksymalne. Wykres kolumnowy reprezentuje liczbę potwierdzonych przypadków zakażeń SARS- CoV-2 w Polsce (A) oraz liczbę zgonów osób zakażonych wirusem SARS-CoV-2 (B) na 100 tysięcy mieszkańców (B).

\section{DISCUSSION}

The conducted studies indicate the variability of the incidence of TBE with its periodic increase in 2016-2017 in two voivodeships with the highest incidence - Podlaskie and Warminsko-Mazurskie. Similar variability is observed in other countries of the region. Based on the studies of the cyclicality of TBE cases in six Central European countries, it is postulated that the changing number of cases may be influenced by both external (e.g. weather) and internal factors - changes in the pathogen's ecosystem (9). The variability of weather components, such as the

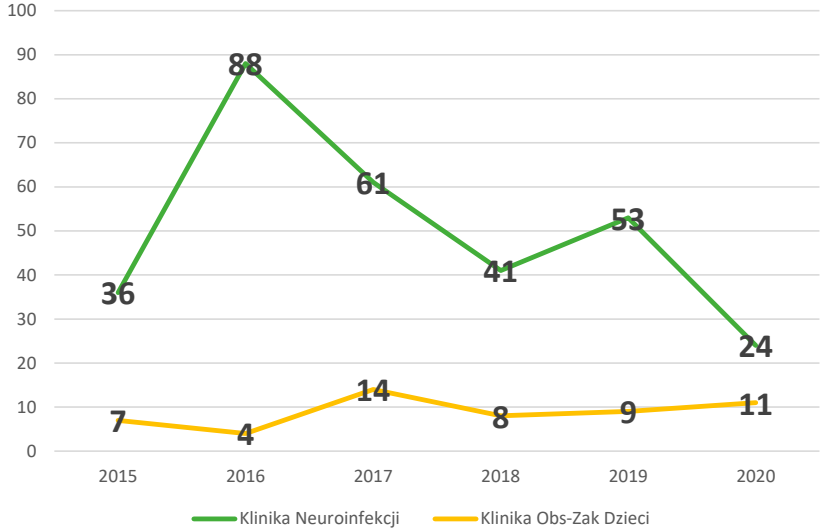

Fig. 5. Number of adult patients hospitalized in the Department of Infectious Diseases and Neuroinfection (green) and children hospitalized in the Department of Pediatric Infectious Diseases (yellow) of Medical University of Bialystok in 2015-2020

Ryc. 5. Liczba pacjentów dorosłych hospitalizowanych w Klinice Chorób Zakaźnych i Neuroinfekcji (kolor zielony) oraz dzieci hospitalizowanych w Klinice ObserwacyjnoZakaźnej Dzieci (kolor żółty Uniwersytetu medycznego w Białymstoku w latach 2015-2020

\section{DYSKUSJA}

Przeprowadzone badania wskazują na zmienność zapadalności na kzm z jej okresowym wzrostem w latach 2016-2017 na terenie dwóch województw o największej zapadalności - województwa podlaskiego oraz warmińsko-mazurskiego. Podobną zmienność obserwuje się $\mathrm{w}$ innych krajach regionu. Na podstawie badań cykliczności zachorowań na kzm w sześciu krajach Europy Środkowej postuluje się, iż wpływ na zmieniającą się liczbę zachorowań mogą mieć zarówno czynniki zewnętrzne (np. pogodowe) jak i wewnętrzne - zmiany ekosystemu czynnika chorobotwórczego (9). Zmienność składników pogody, jak choćby liczba dni słonecznych, może wpływać na skłonność ludzi do korzystania $z$ aktywności na świeżym powietrzu, co przekłada się na liczbę zachorowań na kzm (12). Istotną rolę mogą mieć okresowe wahania dostępności pożywienia dla kluczowego rezerwuaru zwierzęcego, w tym przypadku małych ssaków. Cykle zwierzęce dotyczące małych ssaków są skorelowane z cyklami roślinnymi. W kilku krajach Europy podjęto próby prognozowania zapadalności na kzm w zależności od cyklów owocowania powszechnego gatunku drzew liściastych - buka zwyczajnego (Fagus sylvatica) (13). Cykle o różnych przyczynach mogą nakładać się na siebie, ostatecznie powodując wypadkową obserwowaną zmienność zapadalności. Powyższe obserwacje mogą być podstawą prognozowania liczby zachorowań w nadchodzących latach (12-14). Dane dotyczące zapadalności na kzm w obrębie Federacji Rosyjskiej obejmują okres ponad 80 lat i są podstawą do przewidywania liczby przy- 
number of sunny days, may affect the tendency of people to perform outdoor activities, which translates into the number of people suffering from TBE (12). Periodic fluctuations in food availability for a key animal reservoir, in this case small mammals, may play an important role. The animal cycles of small mammals are correlated with the plant cycles. In several European countries, attempts have been made to forecast the incidence of TBE depending on the fruiting cycles of common species of deciduous trees - European beech (Fagus sylvatica) (13). Cycles of different causes can overlap, ultimately resulting in the observed variability in incidence. The number of TBE cases in the coming years can be forecasted based on the above observations (12-14). Data on the incidence of TBE in the Russian Federation cover a period of more than 80 years and are the basis for predicting the number of cases for the following year (15). Forecasting the incidence in Poland would be possible under the condition of conducting observations in the perspective of several dozen years.

TBE cases in Poland are reported mainly from May to December, which results from the activity of the disease vector and the period of its incubation. Similar data come from Lithuania (16), but in December there were almost no cases of the disease.

The outbreak of the COVID-19 pandemic and the restrictions introduced as a result of it, including the universal order to cover the mouth and nose, obviously affected the incidence of airborne and droplettransmitted diseases. The health consequences of the spread of SARS-CoV-2 virus and the introduced restrictions are also visible in the case of other diseases. The change in human morbidity reduced the incidence of sexually transmitted diseases (17). The COVID-19 pandemic changed the profile of urgent medical interventions by reducing their number $(18,19)$. There are few reports on the impact of the COVID-19 pandemic on the reported incidence of TBE in the available literature. In Switzerland, an analysis of the number of reported cases of droplettransmitted diseases, fecal-oral transmitted diseases and vector-borne diseases (both imported from tropical countries and endemic TBE) was carried out in relation to the long-term average. The study covered a period of twelve weeks of the year 2020 when strict mobility restrictions were introduced. In the analyzed period, there was a decrease in the number of cases in all examined diseases except TBE. An increase in the number of TBE cases by $87 \%$ compared to the 2016-2019 average was observed. The increased outdoor activity of citizens and thus exposure to tick-borne diseases is considered the cause of the abovementioned increase (20). Our own padków na okres kolejnego roku (15). Prognozowanie zapadalności na terenie Polski byłoby możliwe pod warunkiem prowadzenia obserwacji w perspektywie kilkudziesięciu lat.

Przypadki zachorowań na kzm w Polsce raportowane są głównie od maja do grudnia, co wynika z aktywności wektora choroby oraz okresu jej wylęgania. Podobne dane pochodzą z Litwy (16), jednak tutaj już w grudniu niemal nie notowano przypadków zachorowań.

Pandemia choroby COVID-19 w 2020 roku i wprowadzone wraz $\mathrm{z}$ nią ograniczenia, $\mathrm{w}$ tym powszechny nakaz zasłaniania ust i nosa w sposób oczywisty wpłynęła na zapadalność na choroby przenoszone drogą kropelkową i powietrzną. Zdrowotne konsekwencje rozprzestrzeniania się wirusa SARS-CoV-2 i wprowadzonych obostrzeń są widoczne również w przypadku innych chorób. Zmiana zachowań ludzi wpłynęła na zmniejszenie zapadalności na choroby przenoszone drogą płciową (17). Pandemia COVID-19 zmieniła profil pilnych interwencji medycznych redukując ich liczbę $(18,19)$. W dostępnej literaturze niewiele jest doniesień o wpływie pandemii COVID-19 na raportowaną zapadalność na kzm. W Szwajcarii przeprowadzono analizę liczby raportowanych przypadków zachorowań na szereg chorób przenoszonych drogą kropelkowa, fekalno-oralną oraz chorób wektorowych (zarówno zawleczonych z krajów tropikalnych, jak i endemicznie występującego kzm) w odniesieniu do wieloletniej średniej. Badania obejmowały okres dwunastu tygodni 2020 roku, w których obowiązywały ścisłe ograniczenia $\mathrm{w}$ poruszaniu się. $\mathrm{W}$ badanym okresie obserwowano spadek liczby zachorowań na wszystkie badane choroby poza kleszczowym zapaleniem mózgu. Zaobserwowano wzrost liczby przypadków kzm o 87\% w stosunku do średniej z lat 2016-2019 argumentując to wzmożoną aktywnością obywateli na świeżym powietrzu i tym samym narażeniem na choroby przenoszone przez kleszcze (20). Badania własne nie wykazały takiego wzrostu podczas okresu ścisłych ograniczeń z początku 2020 roku, jednak w tym czasie w Polsce zakaz obejmował również wstęp do lasów i tym samym wzmożona aktywność na świeżym powietrzu nie była możliwa. Badania własne wykazują spadek zapadalności na kzm w Polsce wraz ze wzrastającą liczbą zachorowań na COVID-19 od sierpnia 2020 roku. Kleszczowe zapalenie mózgu jest chorobą wektorową i tym samym nie przenosi się bezpośrednio między ludźmi. Stosowane w celu spowolnienia rozprzestrzeniania się zakażenia wirusem SARS-CoV-2 nakazy dystansu społecznego oraz noszenia maseczek zasłaniających usta i nos nie mają wpływu na transmisję choroby. Wydaje się, iż przyczyną obserwowanych zależności może być ograniczenie raportowania związane z przeznaczeniem oddziałów zakaźnych zwyczajowo hospitalizującym 
research did not show such an increase during the period of strict restrictions imposed at the beginning of 2020, but at that time in Poland the mobility restrictions also included forests, and thus increased outdoor activity was not possible. Our own research shows a decrease in the incidence of TBE in Poland along with the increase in the number of COVID-19 cases from August 2020. Tick-borne encephalitis is a vector-borne disease and therefore is not directly transmitted from person to person. Therefore, the social distancing orders and the wearing of masks covering the mouth and nose to slow down the spread of SARS-CoV-2 virus do not affect the transmission of TBE. It seems that the reason for the observed dependencies may be limited reporting related to the fact that at the time infectious wards, where TBE patients are usually treated, were dedicated to hospitalizing patients with COVID-19 disease.

Tick-borne encephalitis may be asymptomatic in a significant percentage of cases, ranging from $70 \%$ to $98 \%$ of all TBEV infections (21). Such cases of the disease are not reported. A symptomatic infection may be limited to non-specific symptoms such as fever, fatigue, muscle pain, nausea and vomiting. A full-blown second phase of the disease occurs in at least one third of patients (22) and is often the cause of hospitalization. In this phase of the disease, $50 \%$ of adult patients show symptoms of meningitis, $40 \%$ develop symptoms of meningitis and encephalitis, while $10 \%$ develop meningoencephalomyelitis (21). Since the symptoms of isolated meningitis may be mild, it can be assumed that because of the overburden of health services with COVID-19 cases these patients could seek help outside specialized hospital wards. It is possible that these cases were not recognized as TBE and were not reported to the sanitary authorities. Such a reason for the decrease in the incidence after August 2020 would be indicated by the fact that, as shown by our own research, the decrease in the number of hospitalizations in Białystok concerned adult patients, while it was not observed in children. The course of SARS-CoV-2 infection in children is much milder than in adults (23), and thus the occupancy rate in pediatric wards during the COVID-19 pandemic was incomparably lower than in adult wards. Our own observations correlate well with previous reports, showing differences in the reported incidence of TBE in various regions of Poland and linking these differences with better diagnostic availability in the two north-eastern voivodeships (10).

The prevention of TBE is possible thanks to an effective and safe vaccine that has been available for decades (24). In the future, the incidence of TBE in Poland will be determined by the percentage of w Polsce pacjentów z kzm do leczenia choroby COVID-19.

Kleszczowe zapalenie mózgu może przebiegać bezobjawowo w znacznym odsetku przypadków sięgającym 70\% do 98\% wszystkich zakażeń TBEV (21). Przypadki te umykają raportowaniu objawowych postaci zakażenia. Objawowe zakażenie może ograniczyć się do mało specyficznych objawów zakażenia, takich jak gorączka, zmęczenie, bóle mięśniowe, nudności i wymioty. Pełnoobjawowa druga faza choroby występuje u co najmniej jednej trzeciej pacjentów (22) i często jest przyczyną hospitalizacji. W tej fazie choroby $50 \%$ dorosłych pacjentów prezentuje objawy zapalenia opon mózgowo-rdzeniowych, u dalszych $40 \%$ występują objawy zapalenia opon mózgowych i mózgu, podczas u 10\% rozwija się meningoencephalomyelitis (21). Ponieważ objawy izolowanego zapalenia opon mózgowo-rdzeniowych mogą być słabo nasilone, można przypuszczać, że w okresie przeciążenia służby zdrowia przypadkami COVID-19 pacjenci ci mogli poszukiwać pomocy poza specjalistycznym oddziałem szpitalnym. Przypadki te mogły nie być rozpoznawane jako kzm i nie zostały raportowane do władz sanitarnych. Na taką przyczynę spadku zapadalności po sierpniu 2020 roku wskazywałby fakt, iż jak wykazały badania własne spadek liczby hospitalizacji w Białymstoku dotyczył jedynie ośrodka zajmującego się dorosłymi pacjentami, podczas gdy nie obserwowano takiego spadku u dzieci. Przebieg zakażenia wirusem SARS-CoV-2 u dzieci jest dużo łagodniejszy niż u dorosłych (23) i tym samym obciążenie pediatrycznych oddziałów szpitalnych w czasie pandemii COVID-19 jest nieporównywalnie mniejsze niż oddziałów hospitalizujących dorosłych. Obserwacje własne dobrze korelują z wcześniejszymi doniesieniami wykazującymi różnice $\mathrm{w}$ raportowanej zapadalności na KZM pomiędzy regionami Polski i wiążącymi te różnice z lepszą dostępnością diagnostyki w dwóch północno-wschodnich województwach (10).

Zapobieganie kleszczowemu zapaleniu mózgu jest możliwe dzięki skutecznej i bezpiecznej szczepionce, która jest dostępna od dekad (24). W przyszłej perspektywie zapadalność na kzm w Polsce będzie warunkowana przez odsetek populacji, który będzie chciał z tej możliwości skorzystać.

\section{WNIOSKI}

W badanym okresie 2010-2019 największą zapadalność na kzm notuje się w Polsce stale w dwóch województwach: podlaskim i warmińsko-mazurskim. Zapadalność na kzm zmienia się rok do roku. Pandemia choroby COVID-19 wpłynęła na zmniejszenie liczby raportowanych przypadków kzm w Polsce. Jedną z potencjalnych przyczyn jest przeciążenie specjalistycz- 
the population willing to take advantage of this opportunity.

\section{CONCLUSIONS}

In the analyzed period of 2010-2019, the highest incidence of TBE in Poland was constantly recorded in two voivodeships: Podlaskie and WarminskoMazurskie. The incidence of TBE varies from year to year. The COVID-19 pandemic has reduced the number of reported TBE cases in Poland. One of the potential causes is the overload of specialist hospital units dedicated to fighting COVID-19. TBE diagnosis should be taken into account whenever central nervous system symptoms are reported, regardless of the place of hospitalization.

\section{REFERENCES}

1. Dekker M, Laverman GD, de Vries A, et al. Emergence of tick-borne encephalitis (TBE) in the Netherlands. Ticks Tick Borne Dis 2019; 10: 176-9.

2. Holding M, Dowall SD, Medlock JM, et al. TickBorne Encephalitis Virus, United Kingdom. Emerg Infect Dis 2020; 26: 90-6.

3. Petri E, Gniel D, Zent O. Tick-borne encephalitis (TBE) trends in epidemiology and current and future management. Travel Med Infect Dis 2010; 8: 233-45.

4. Markovinović L, Kosanović Ličina ML, Tešić $\mathrm{V}$, et al. An outbreak of tick-borne encephalitis associated with raw goat milk and cheese consumption, Croatia, 2015. Infection 2016; 44: 661-5.

5. Król ME, Borawski B, Nowicka-Ciełuszecka A, et al. Outbreak of alimentary tick-borne encephalitis in Podlaskie voivodeship, Poland. Przegl Epidemiol 2019; 73: 239-48.

6. Zeman P, Bene C. A tick-borne encephalitis ceiling in Central Europe has moved upwards during the last 30 years: possible impact of global warming? Int J Med Microbiol 2004; 293 Suppl 37: 48-54.

7. Michelitsch A, Wernike K, Klaus C, et al. Exploring the Reservoir Hosts of Tick-Borne Encephalitis Virus. Viruses 2019; 11: 669.

8. Moshkin MP, Novikov EA, Tkachev SE, et al. Epidemiology of a tick-borne viral infection: theoretical insights and practical implications for public health. Bioessays 2009; 31: 620-8.

9. Zeman P. Cyclic patterns in the central European tick-borne encephalitis incidence series. Epidemiol Infect 2017; 145: 358-67.

10. Stefanoff P, Rubikowska B, Bratkowski J, et al. A Predictive Model Has Identified Tick-Borne Encephalitis High-Risk Areas in Regions Where nych oddziałów szpitalnych przeznaczonych do walki $z$ chorobą COVID-19. Zachorowanie na kzm powinno być brane pod uwagę w każdym przypadku zgłaszania objawów ze strony ośrodkowego układu nerwowego, bez względu na miejsce hospitalizacji.

No Cases Were Reported Previously, Poland, 1999-2012. Int J Environ Res Public Health 2018; 15: 677.

11. Stefanoff P, Zielicka-Hardy A, Hlebowicz M et al. TBE enhanced surveillance working group. New endemic foci of tick-borne encephalitis (TBE) identified in districts where testing for TBE was not available before 2009 in Poland. Parasit Vectors 2013; 6: 180.

12. Rubel F, Walter M, Vogelgesang JR, et al. Tickborne encephalitis (TBE) cases are not random: explaining trend, low- and high-frequency oscillations based on the Austrian TBE time series. BMC Infect Dis 2020 26; 20: 448.

13. Rubel F, Brugger K. Operational TBE incidence forecasts for Austria, Germany, and Switzerland 2019-2021. Ticks Tick Borne Dis 2021; 12: 101579.

14. Rubel F, Brugger K. Tick-borne encephalitis incidence forecasts for Austria, Germany, and Switzerland. Ticks Tick Borne Dis 2020; 11: 101437.

15. Nikitin AY, Andaev EI, Yatsmenko EV, et al. Epidemiological Situation on Tick-Borne Viral Encephalitis in the Russian Federation in 2019 and Forecast for 2020. Problems of Particularly Dangerous Infections 2020; 1: 33-42.

16. Radzišauskienė D, Urbonienė J, Kaubrys $G$, et al. The epidemiology, clinical presentation, and predictors of severe Tick-borne encephalitis in Lithuania, a highly endemic country: A retrospective study of 1040 patients. PLoS One 2020; 15: e0241587.

17. Ogunbodede OT, Zablotska-Manos I, Lewis DA. Potential and demonstrated impacts of the COVID-19 pandemic on sexually transmissible infections. Curr Opin Infect Dis 2021; 34: 56-61.

18. Steinman M, de Sousa JHB, Tustumi F, et al. The burden of the pandemic on the non-SARS-CoV-2 emergencies: A multicenter study. Am J Emerg Med 2021; 42: 9-14.

19. Kucap M, Nadolny K, Ładny JR, et al. Retrospective analysis of interventions performed by emergency medical teams in Poland before and during the SARS-CoV-2 pandemic. Wiad Lek 2020; 73: 1659-62.

20. Steffen R, Lautenschlager S, Fehr J. Travel restrictions and lockdown during the COVID-19 pandemic-impact on notified infectious diseases in Switzerland. J Travel Med 2020; 27: taaa180. 
21. Bogovic P, Strle F. Tick-borne encephalitis: A review of epidemiology, clinical characteristics, and management. World J Clin Cases 2015; 3: 430-41.

22. Ruzek D, Avšič Županc T, Borde J, et al. Tickborne encephalitis in Europe and Russia: Review of pathogenesis, clinical features, therapy, and vaccines. Antiviral Res 2019; 164: 23-51.

23. Wang F, Lai CX, Huang PY, et al. Comparison of Clinical Characteristics and Outcomes of Pediatric and Adult Patients with Coronavirus Disease 2019 in Shenzhen, China. Biomed Environ Sci 2020; 33: 906-15.

24. Kunz C. TBE vaccination and the Austrian experience. Vaccine 2003; 21 Suppl 1: S50-55.
Received: 08.04.2021

Otrzymano: 08.04.2021 r.

Accepted for publication: 21.06.2021

Zaakceptowano do publikacji: 21.06.2021 r.

\section{Address for correspondence:}

Adres do korespondencji:

Dr hab. n med. Sambor Grygorczuk

Uniwersytet Medyczny w Białymstoku

Klinika Chorób Zakaźnych i Neuroinfekcji

ul. Żurawia 14,

15-540 Białystok

tel. (85) 8316514

sambor.grygorczuk@umb.edu.pl 